\title{
A SYNERGISTIC INSULINOTROPIC EFFECT OF GREEN TEA EXTRACT AND POMEGRANATE EXTRACT WITH ROSIGLITAZONE: BOTH IN VIVO AND IN VITRO EXPERIMENT
}

\author{
REKHA $S^{1 *}$, CHANDRASHEKHARA $S^{2}$
}

${ }^{1}$ Department of Pharmaceutical Chemistry, College of Pharmaceutical Sciences, Dayananda Sagar University, Bengaluru, Karnataka, India. ${ }^{2}$ Department of Pharmaceutics, Dr. Ravi Patil College of Pharmacy, Belgaum, Karnataka, India. Email: rekha.maheshh@gmail.com

Received: 24 June 2020, Revised and Accepted: 05 August 2020

\section{ABSTRACT}

Objective: Scientists have growing interest in traditional medicinal plants as they contain active ingredients for the treatment of various diseases. Tea is one of the most popular beverages worldwide. The variety of tea and tea extracts in the market has different polyphenol profiles, which are the bioactive chemical entities. We performed a direct comparison between Thea sinensis, green tea extracts (GTEs), and Punica granatum peel powder (PGPP), which have been chemically well characterized in a type II diabetic mouse model.

Methods: We conducted both in vivo and in vitro experiments in the present paper. In vivo studies were carried out on male Swiss albino rats having type II diabetes, induced by single intravenous injection of streptozotocin ( $0.7 \mathrm{mg} / \mathrm{Kg}$ i.m.) and IDDM rats received either PGPP (200 mg/kg) or GTE $(100 \mathrm{mg} / \mathrm{kg})$ as a single oral dose. After the above result, the extracts were further subjected to know the effect of insulin secretion by RIN-5F cells providing confirmation of insulinotropic effect.

Results: The results revealed that both PGPP and GTE substantially lowered blood glucose levels and ameliorated glucose intolerance, both were effective in antihyperglycemic activity and in lowering body weight gain. Serum insulin levels significantly increased in GTE group as well as in PGPP group, suggesting that they were exerting hypoglycemic effects through different pathways.

Conclusion: Synergistic action of PGPP and GTE is an effective alternative for the treatment of type II diabetes through the regeneration of $\beta$ cells of pancreas.

Keywords: Diabetes, Thea sinensis, Punica granatum, Streptozocin, Pancreas, $\beta$-cells, Antihyperglycemic activity.

(c) 2020 The Authors. Published by Innovare Academic Sciences Pvt Ltd. This is an open access article under the CC BY license (http://creativecommons. org/licenses/by/4. 0/) DOI: http://dx.doi.org/10.22159/ajpcr.2020.v13i10.38850

\section{INTRODUCTION}

Hyperglycemia is a chronic disorder accompanied by raise in blood glucose level which results in the interruption of the various metabolisms and brings about secondary complications such as hypertension, cardiovascular diseases, and diabetic neuropathy. There is a critical need for the management of type II diabetes mellitus [1]. Plants and their derived preparations have comprehensively used as traditional remedies for the treatment of diabetes all over the globe. Some of the plants were identified scientifically and evaluated for the beneficial effects in diabetes; they include cinnamon, cloves, ginger, garlic, cumin, and green tea [2].

Thea sinensis belongs to the family Theaceae whose leaves and leaf buds are used to produce tea and commonly known as "tea plant." A small number of studies have confirmed that green tea extract (GTE) contains polyphenols and epigallocatechin gallate is favorable for the treatment of hyperglycemia, and a probable mechanism can be ascribed to their inhibitory effect against $\alpha$-amylase and $\alpha$-glucosidase in the intestinal tract [3].

One of the potential agents for future diabetic therapy is pomegranate obtained from Punica granatum (PG), belonging to the family of Punicaceae that contains flavonoid, proanthocyanidin, ellagitannin, and gallotannin. They are verified to protect pancreatic beta-cells from free radicals damage [4].

In this paper, we investigated the combined effect of GTEs and PG peel powder (PGPP) with standard reference rosiglitazone on RIN$5 \mathrm{~F}$ cells in vitro, which include a range of studies such as reduced or inhibited glucose absorption at intestinal level and peripheral level, by facilitating the entry of glucose into cells. The in vivo studies included the stimulation of $\beta$ pancreatic cells to release insulin in insulinsensitive tissues [5].

\section{METHODS}

Drugs and chemicals

Streptozotocin

[N-(Methylnitrosocarbamoyl)- $\alpha$-D-glucosamine] procured from Sigma, St. Louis, MO, USA. Other chemicals used throughout this investigation were of the highest analytical grade available.

\section{Rosiglitazone}

Rosiglitazone is an oral hypoglycemic drug in the thiazolidinedione class of drugs. It works as an insulin sensitizer, by binding to the PPAR gamma receptors [6].

Plant material fresh PG fruits were purchased from local markets, India. Fruits were cut into portions and arils were separated manually from peels. The peels were cut into small pieces and sun dried until complete dehydration. Dried peels were grounded into fine powder in a mortar. Peels powder was kept in an airtight plastic container and stored at $5^{\circ} \mathrm{C}$ until used. Peels powder was suspended in warm distilled water $(100$ $\mathrm{mg} / 1 \mathrm{ml}$ ) and was given orally through the stomach tube to rats at a dose of $200 \mathrm{mg} / \mathrm{kg}$ [7].

Green tea water extracts (GTEs) were purchased from Tata Global Beverages Instant Tea Division (Munnar, Kerala 685612).

In vivo and in vitro screening for antidiabetic activities

Streptozocin-induced insulin resistance in rats

Exogenous administration of streptozocin in rats causes hyperglycemia, hyperinsulinemia, and associated with insulin resistance. Institution 
of Animals Ethics Committee has approved the experimental protocol (DSU/PhD/IAEC/09/2017-18).

\section{Animals [8,9]}

Male Sprague-Dawley (SD) rats (150-200 g) were obtained from the Animal House of the School of Pharmaceutical Sciences, Dayananda Sagar University, Bengaluru. They were housed in standard environmental conditions $\left(24 \pm 1^{\circ} \mathrm{C}\right)$ with $12 \mathrm{~h}$ light: $12 \mathrm{~h}$ dark cycles and fed a commercial diet and water ad libitum.

\section{Streptozotocin-induced diabetic rats [10-12]}

Diabetes was induced by intraperitoneal injection of streptozotocin (Sigma-Aldrich) $(65 \mathrm{mg} / \mathrm{kg}$ body weight in $0.9 \% \mathrm{NaCl}, \mathrm{pH} 4.5)$ to rats fasted for $16 \mathrm{~h}$. Their diabetic conditions were confirmed by the symptoms of polydipsia, polyuria, and a high fasting blood glucose concentration $72 \mathrm{~h}$ after injection of streptozotocin. Rats with a blood glucose level above $15.0 \mathrm{mmol} / \mathrm{L}$ were considered to be diabetic and used in the experiment 14 days treatment with the $6 \mathrm{a}$ and $6 \mathrm{~b}$

Group I: Normal control - Received 0.25\% CMC p.o and sterile water for injection i.m.

Group II: Streptozocin control - Received 0.25\% CMC p.o and streptozocin $0.7 \mathrm{mg} / \mathrm{Kg}$ i.m.

Group III: Rosiglitazone treated - Received rosiglitazone $0.72 \mathrm{mg} / \mathrm{kg}$ in $0.25 \%$ CMC p.o and streptozocin $0.7 \mathrm{mg} / \mathrm{Kg}$ i.m.

Group IV: Received PGPP, 200 mg/Kg in 0.25\% CMC p.o and streptozocin $0.7 \mathrm{mg} / \mathrm{Kg}$ i.m.

Group V: Received GTE, $100 \mathrm{mg} / \mathrm{Kg}$ in $0.25 \%$ CMC p.o and streptozocin $0.7 \mathrm{mg} / \mathrm{Kg}$ i.m.

Treatment was continued for 10 days. On day 10, after overnight fasting, blood samples were collected from all the animals by puncturing the retro-orbital plexus under mild ketamine anesthesia.

In vitro studies using RIN-5F cells [13-15]

RIN-5F cells (rat pancreatic beta cell line) were routinely cultured in RPMI 1640 supplemented with $2 \mathrm{mM}$ L-glutamine, $10 \mathrm{mM}$ HEPES, $1 \mathrm{mM}$ sodium pyruvate, $4.5 \mathrm{~g} / \mathrm{L}$ glucose, $1.5 \mathrm{~g} / \mathrm{L}$ sodium bicarbonate, and $10 \%$ fetal bovine serum. The cells were passaged $2-4$ days before each experiment and plated in 24-well Nunclon multiwell plates (NUNC $\mathrm{A} / \mathrm{S}$, Denmark) at a density of $0.2 \times 10^{6}$ cells/well. Insulin secretion was measured as previously described by Gray and Flatt (1998, 1999). Multiwells were seeded with $0.2 \times 10^{6}$ cells and insulin release measured after 4-5 days as follows. Cells were washed three times with KRB (115 mM NaCl, 4.7 mM KCl, $1.28 \mathrm{mM} \mathrm{CaCl} 2,1.2 \mathrm{mM} \mathrm{KH2PO4,}$
$1.2 \mathrm{mM}$ MgSO4, $24 \mathrm{mM}$ NaHCO3, $10 \mathrm{mM}$ HEPES-free acid, $1 \mathrm{~g} / \mathrm{L}$ bovine serum albumin, and $1.1 \mathrm{mM}$ glucose; $\mathrm{pH}$ 7.4) and preincubated for $40 \mathrm{~min}$ at $37^{\circ} \mathrm{C}$. Cells were then incubated for $20 \mathrm{~min}$ with $1 \mathrm{~mL} \mathrm{KRB}$ and $1.1 \mathrm{mM}$ glucose in the presence of PGPP and GTE. Following incubation, aliquots were removed from each well and stored at $-20^{\circ} \mathrm{C}$ for insulin assay. Insulin release was measured by rat an insulin enzyme-linked immunosorbent assay (ELISA) kit (Crystal Chem, USA).

\section{Cell viability [16]}

The 3-(4, 5-dimethylthiazol-2-yl)-2, 5-diphenyltetrazolium bromide (MTT) assay which is based on the cleavage of a tetrazolium salt by mitochondrial dehydrogenases in viable cells (Hansen et al., 1989) used to estimate cell viability. Briefly, cells were added onto flatbottomed microculture plates in the presence or absence of various concentrations of the extracts (in triplicate) and incubated at $37^{\circ} \mathrm{C}$ in a $5 \%$ humidified $\mathrm{CO}_{2}$ incubator for 24 and $48 \mathrm{~h}$. Then, $10 \mathrm{~mL}$ of MTT ( $5 \mathrm{mg} / \mathrm{mL}$, Sigma) was added to each well and incubation was continued for a further $4 \mathrm{~h}$ at $37^{\circ} \mathrm{C}$. In each well, $100 \mu \mathrm{L} /$ well of solubilization solution, containing dimethyl sulfoxide and Sorenson buffer, were added. After complete solubilization of the dye, plates were read at $570 \mathrm{~nm}$ on an ELISA reader. The mean optical density (OD) \pm SD for each group of replicates was calculated. The whole procedure was repeated for 3 times. The inhibitory rate of cell growth was calculated using the formula:

$\%$ Growth inhibition $=(1-$ OD extract treated $) / O D$ negative control $\times$ 100

\section{RESULTS}

Body weight: There was a momentous reduction in the weight of the animals in the streptozotocin-induced diabetic group with comparison to control. After supplementation with PGPP and GTE for 14 days, the body weight was notably regained. After 21 days of the supplementation, the animals started to gain their normal weight. With insulin treatment for 21 days, diabetic rats began to regain weight to a lesser extent, as shown in Fig. 1 [6].

\section{DISCUSSION}

Hyperglycemia is said to be one of the most well-known health crisis in the world. Best treatment is important to control diabetic complications. Natural products and their active phytochemicals have brilliant biological activity in vitro and in vivo.

In many research papers, the studies were restricted only on PG [1] or GTE [4] for antidiabetic activity. In the current delve into, we made a realistic approach to improve the compound therapy of active phytoconstituents using them day by day in our usual food. Green tea, one of the comprehensively used beverages in the world,

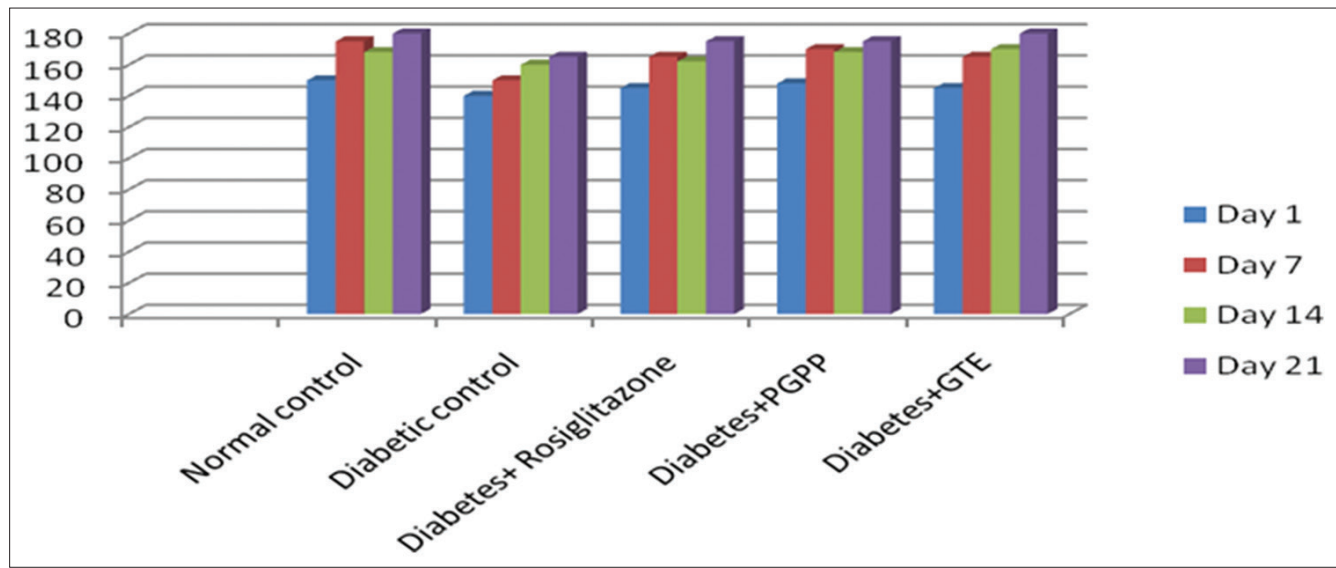

Fig. 1: Changes in rats' body weight (g). Each bar represents the mean \pm SD of rats. PGPP: Punica granatum peel powder and GTE: Green tea extract. Values were expressed as mean \pm SD. PGPP: Punica granatum peel powder, GTE: Green tea extract 
is renowned in the avoidance of hyperglycemia $[17,18]$. PG is used as remedy in handling of variety of diseases. It also serves as a therapy for diabetes [19]. In Fig. 1, we reported the effects of PGPP and GTE on streptozocin-induced type II diabetic rats. The treatment

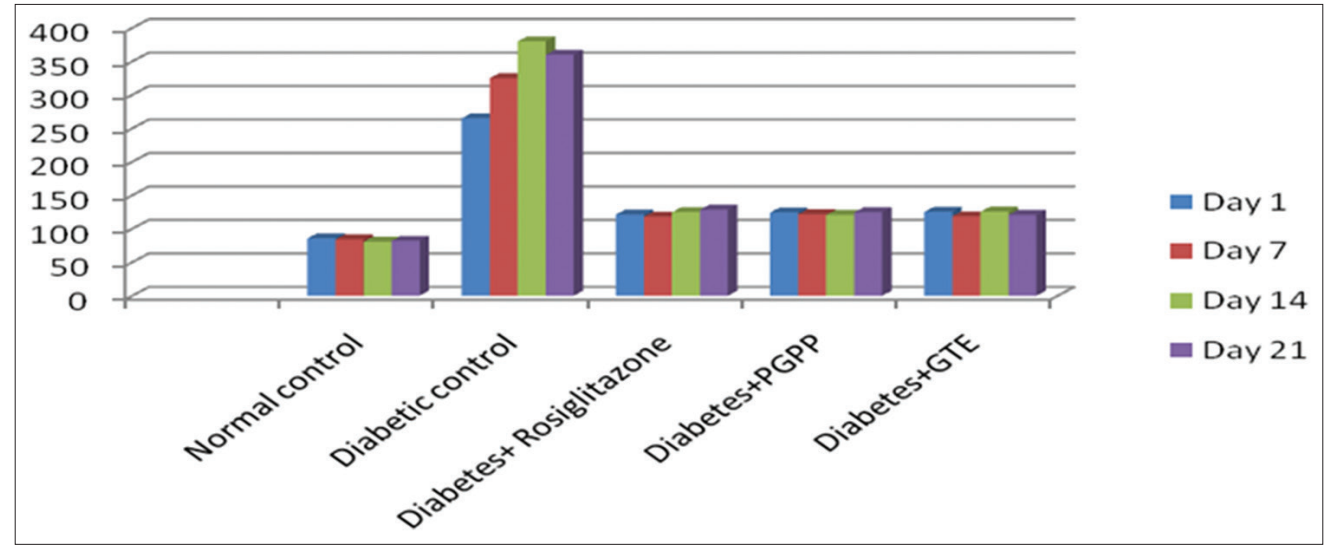

Fig. 2: Effect of derivatives on blood glucose levels (mg/dl) in streptozocin-induced insulin resistance model in rats. Fasting blood glucose level in the PGPP and GTE treated rats, decrease in blood glucose level was prominent from day 7 onward; the decrease in blood glucose level was highly pronounced on the day 21 . The hypoglycemic effect of PGPP at $200 \mathrm{mg} / \mathrm{kg}$ and GTE at $100 \mathrm{mg} / \mathrm{kg} \mathrm{dose} \mathrm{was} \mathrm{more}$ prominent than rosiglitazone (the reference standard). Values were expressed as mean \pm SD. PGPP: Punica granatum peel powder, GTE: Green tea extract

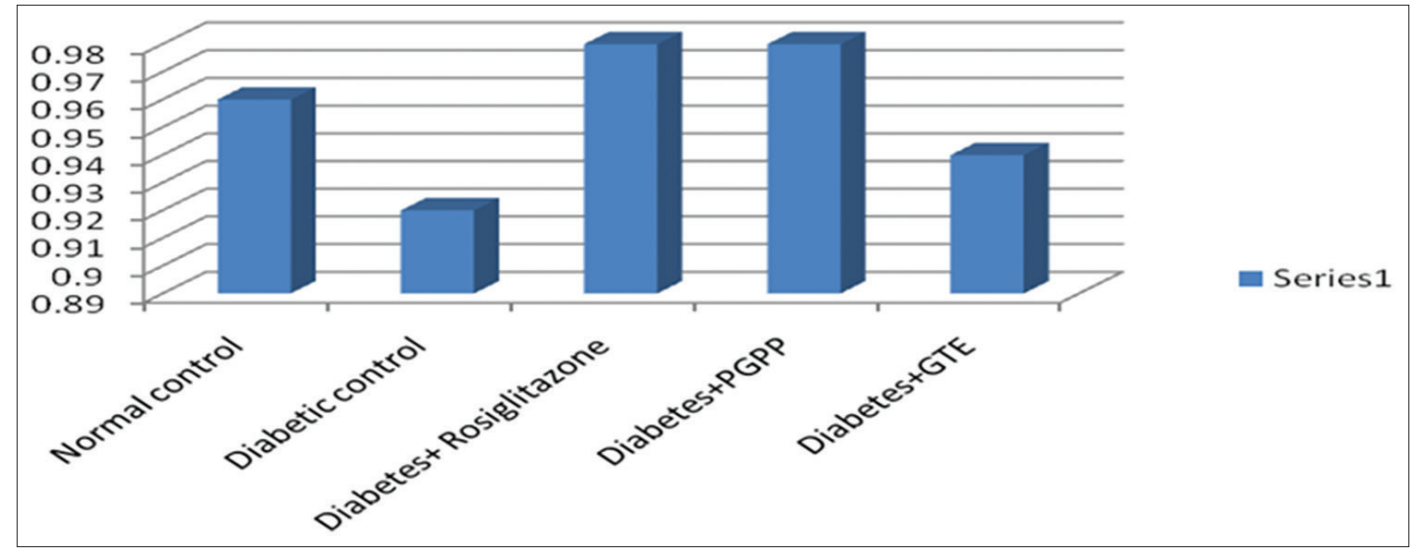

Fig 3: Effects of derivatives on insulin secretion by RIN-5F cells [9]. Rosiglitazone (0.2-20 mM) produced a dose-dependent stimulatory effect on insulin secretion by RIN-5F cells incubated in $1.1 \mathrm{mM}$ glucose. RIN-5F cells exposed to $20 \mathrm{mM}$ of rosiglitazone for 20 min showed maximal levels of stimulation. However, concentrations of rosiglitazone $<20 \mathbf{~ m M}$ did not significantly enhance the insulin-releasing effect. As seen in the treatment of RIN-5F cells with different concentrations of PGPP and GTE $(10 \mathrm{mg} / \mathrm{mL})$ significantly increase the levels of insulin as compared with the control. Each value represents the mean \pm SEM $(n=6)$; ${ }^{*}$ indicates significant difference between treated groups compared with control group without rosiglitazone at $\mathbf{p}<0.05$. Values were expressed as mean \pm SD. PGPP: Punica granatum peel powder, GTE: Green tea extract

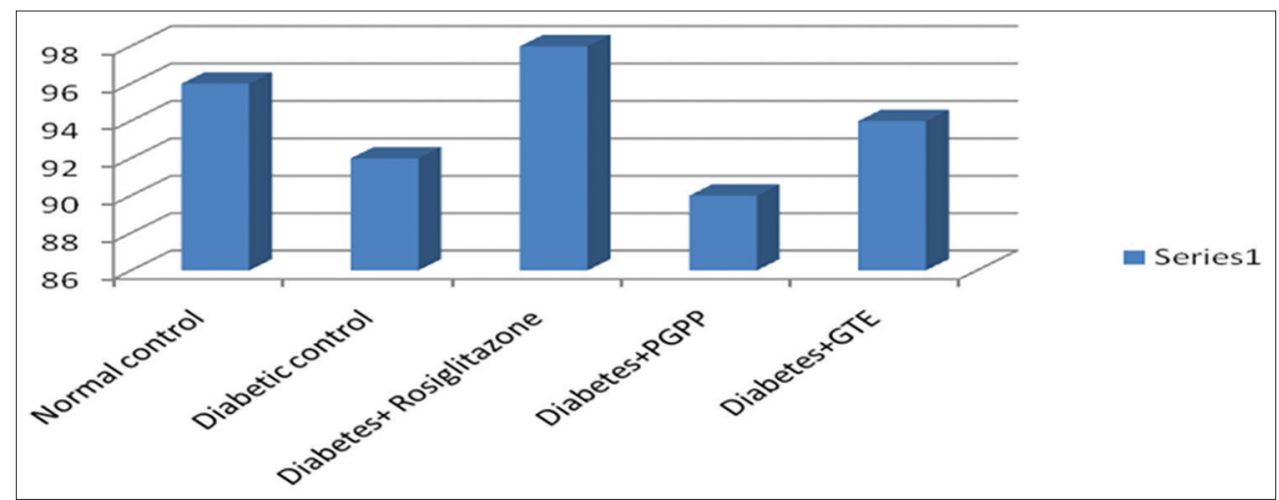

Fig. 4: MTT assay/percentage cell viability of rosiglitazone, PGPP, and GTE. A $10 \mathrm{~mL}$ of MTT $(5 \mathrm{mg} / \mathrm{mL}$, Sigma) was added to each of the four wells containing rosiglitazone, PGPP, and GTE at concentrations of $10 \mathrm{mg} / \mathrm{mL}$ showed no cytotoxic effect in RIN-5F cells. Incubation was continued for a further $4 \mathrm{~h}$ at $37^{\circ} \mathrm{C}$. In each well, $100 \mu \mathrm{L} /$ well of solubilization solution, containing dimethyl sulfoxide and Sorenson

buffer, were added. After complete solubilization of the dye, plates were read at $570 \mathrm{~nm}$ on an enzyme-linked immunosorbent assay reader. Values were expressed as mean \pm SD. PGPP: Punica granatum peel powder, GTE: Green tea extract, MTT: 3-(4, 5-dimethylthiazol-2- 
continued for 21 days and this resulted in dissimilarity in the body weight between treated and untreated rats. These improvements were observed due to increased relaxation in diabetic rats, due to the decrease in blood glucose level. This proves that PGPP and GTE administration can minimize non-insulin-dependent diabetes symptoms.

As shown in Fig. 2, in vivo studies of PGPP and GTE at $200 \mathrm{mg} / \mathrm{kg}$ and $100 \mathrm{mg} / \mathrm{kg}$ in respective doses are more eminent than rosiglitazone to produce insulinotropic effect in type II diabetic rats; it is proved from the $7^{\text {th }}$ day to $21^{\text {st }}$ day reduce in blood glucose levels which were highly evident, this is due to inhibitory action of the extracts on absorption of glucose at intestinal levels.

In addition, PGPP and GTE treatment restored and observations were recorded on the regeneration of $\beta$-cells of the pancreas [20]. This guarantees that both have protective effects on RIN-5F cells and adds extra confirmation for its hypoglycemic properties including increased insulin sensitivity and inhibition of $\alpha$-glucosidase and $\alpha$-amylase in-vitro, as shown in Fig. 3.

The cell viability effects of both the extracts were studied on cell culture and determined by MTT assay, as shown in Fig. 4, and both were potentially capable and they showed less cytotoxicity effect.

On the scrutiny of the above sighting, it is elective that both the extracts are gifted source for insulinotropic activity both in vitro and in vivo. We promise that both could be noteworthy and favorable agents in preventing the degenerative diseases and a range of other human ailments.

\section{CONCLUSION}

Using a two-way experimental design, the consequence of combinations of PGPP and GTE was considered and analyzed. Both the extracts were synergistic in action. PGPP potentiates the insulinotropic effect of GTE. We trust that they will be precious for future investigations as prospective multitarget-oriented remedies for type II diabetes.

\section{ACKNOWLEDGMENT}

I sincerely thank Management and Dr. V. Murugan, Dean, College of Pharmaceutical Sciences, Dayananda Sagar University, Kumaraswamy layout, Bengaluru, for providing me an opportunity to embark on this project.

\section{AUTHORS' CONTRIBUTIONS}

All the authors have equal contribution for the manuscript preparation, and especially edited, and the final copy was revised by Dr. Chandrashekhar S.

\section{CONFLICTS OF INTEREST}

The authors declared no conflicts of interest.

\section{AUTHORS' FUNDING}

Not applicable.

\section{REFERENCES}

1. Gao J, Xu P, Wang Y, Wang Y, Hochstetter D. Combined effects of green tea extracts, green tea polyphenols or epigallocatechin gallate with acarbose on inhibition against $\alpha$ amylase and $\alpha$-glucosidase in vitro. Molecules 2013;18:11614-623.

2. Salim KS. Hypoglycemic property of ginger and green tea and their possible mechanisms in diabetes mellitus. Open Conf Proc J 2014;5:13-9.

3. Fu QY, Li QS, Lin XM, Qiao RY, Yang R, Li XM, et al. Antidiabetic effects of tea. Molecules 2017;22:849-58.

4. Baliga MS, Shivashankara AR, Shetty CB, Thilakchand KR, Periera N, Palatty PL. Antidiabetic effects of Punica granatum (pomegranate): A review. In: Watson RR, Preedy V, editors. Bioactive Food as Dietary Interventions for Diabetes. $1^{\text {st }}$ ed. New York: Academic Press; 2013. p. 355-69.

5. Tanga W, Lia S, Liub Y, Huang MT, Ho CT. Anti-diabetic activity of chemically profiled green tea and black tea extracts in a Type 2 diabetes mice model via different mechanisms. J Func Foods 2013;5:1784-93.

6. Jain A, Pramodkumar PG. In silico comparative molecular docking study and analysis of glycyrrhizin from Abrus precatorius (L.) against antidiabetic activity. Eur J Med Plants 2015;6:212-22.

7. Saad EA, Hassanien MM, El-hagrasy MA, Radwan KH. Antidiabetic, hypolipidemic and antioxidant activities and protective effects of punica granatum peels powder against pancreatic and hepatic tissues injuries in streptozotocin induced iddm in rats. Int J Pharm Pharm Sci 2015;7:397-402

8. Cheng KH, Fu YC, Rong SL, Moon JY. iGEMDOCK: A graphical environment of enhancing GEMDOCK using pharmacological interactions and post-screening analysis. BMC Bioinformatics 2011;12:33-6.

9. Hassan Z, Yam MF, Ahmad M, Yusof AP. Antidiabetic properties and mechanism of action of Gynura procumbens water extract in streptozotocin-induced diabetic rats. Molecules 2010;15:908-23.

10. Rekha S, Chandrashekhara S. In silico proportional molecular docking study and analysis of insulinotropic activity of TZD derivatives by PPAR $\gamma$ activation. J Pharm Sci Res 2017;9:1799-808.

11. Anindita B, Bithin M, Sandip M, Kaushik C, Tapan S. In-vitro antidiabetic and anti-oxidant activities of ethanol extract of Tinospora sinesis. Int J Curr Pharm Res 2017;9:379-84.

12. Ahmed AT, Belal SK, Salem AG. Protective effect of pomegranate peel extract against diabetic-induced renal pathological histo-changes in albino rats. IOSR JDMS 2014;13:94-105.

13. David AN, Welsh M, Casadaban MJ, Steiner DF. Control of insulin gene expression in pancreatic $\beta$-cells and in an insulin-producing cell line, RIN-5F Cells. J Biol Chem 1985;260:13585-9.

14. Al Nahdi AM, Annie J, Haider R. Elucidation of molecular mechanisms of streptozotocin-induced oxidative stress, apoptosis, and mitochondrial dysfunction in rin-5F pancreatic $\beta$-cells. Hind Oxid Med Cell Long 2017;2017:7054272.

15. Parka JH, Choa KI, Namb H, Choec NH, Suh JG. Anti-apoptotic effects of silk fibroin hydrolysate in RIN5F cell on high glucose condition. Anim Cells Sys 2015;19:201-7.

16. Sepehr KS, Baradaran B, Mazandarani M, Khori V, Shahneh FZ. Studies on the cytotoxic activities of Punica granatum L. var. Spinosa (apple Punice) extract on prostate cell line by induction of apoptosis. Int Sch Res Net 2012;2012:547942.

17. Polychronopoulos E, Zeimbekis A, Kastorini CM, Papairakleous N, Vlachou I, Bountziouka V, et al. Effect of black and green tea consumption on blood glucose levels in non-obese elderly men and women from mediterranean islands (MEDIS epidemiological study). Eur J Nutr 2008;47:10-6.

18. Kuttan R. Anti-diabetic activity of green tea polyphenols and their role in reducing oxidative stress in experimental diabetes. J Ethnopharmacol 2002;83:109-16.

19. Moghaddam G, Sharifzadeh M, Hassanzadeh G, Khanavi M, Hajimahmoodi M. Anti-ulcerogenic activity of the pomegranate peel (Punica granatum) methanol extract. Food Nut Sci 2013;4:43-8.

20. Nogueira DG, Pereira NA. Effect of an alcoholic extract from the pericarp of roma (Punica grantum L.) on insulin hypoglycaemia mice. Rev Bras Farm 1986;67:59-62. 